\title{
Can Foreign Ownership Reduce Bank Risk? Evidence from Vietnam
}

\author{
TU DQ LE \\ University of Economics and Law and Vietnam National University*
}

\begin{abstract}
This study investigates the impact of foreign ownership on bank risk in Vietnam between 2006 and 2015. Our findings show that foreign ownership can lower bank risk, suggesting that the State Bank of Vietnam should further remove restrictions on foreign investments in the banking system. The findings also indicate that higher bank risk is associated with greater technical efficiency, suggesting that the skimping-cost hypothesis may exist. The same conclusion is true for large banks, for banks with higher liquid assets, and those with greater loan growth. More interestingly, we do find evidence that state-owned banks with a greater level of foreign share are likely more stable. This is also true for the case of listed banks with a higher level of foreign ownership.
\end{abstract}

Keywords: Bank risk, foreign ownership, Vietnam, GMM

JEL Classifications: G21

\section{Introduction}

Deregulation and globalization are one of the primary drivers of foreign investment in emerging countries. Several studies have been documented the benefits of foreign ownership in countries such as improving financial services and having easier access to international financial markets (Levine 1996); enhancing market discipline and the competition in the host country (Claessens and Horen, 2014). These countries, however, have implemented a broad range of national policies to restrict the inflow of foreign capital because of the perceived risks from financial openness. This study attempts to examine whether foreign ownership improves banks' solvency.

There is a large volume of studies that have examined the impact of foreign ownership on banking risk in the host country. Empirical studies using cross-country data have shown mixed findings. Laeven (1999) foreign-owned banks tend to take more risk than other types of bank

\footnotetext{
* Institute for Development and Research in Banking Technology, University of Economics and Law, Ho Chi Minh City, Vietnam and Vietnam National University, Ho Chi Minh City, Vietnam. E-mail: tuldq@uel.edu.vn. This research is funded by the University of Economics and Law, Vietnam National University, Ho Chi Minh City, Vietnam.

(C) 2021 Tu Dq Le; . Licensed under the Creative Commons Attribution - Noncommercial 4.0 Licence (http://creativecommons.org/licenses/by-nc/4.0/. Available at http://rofea.org.
} 
ownership in the East-Asia region. This is in line with the findings of Yeyati and Micco (2007) in the Latin-America. In contrast, Crystal et al. (2002) suggest that foreign banks are more prudent than local banks in emerging markets. Besides, several banking studies have investigated the impact of foreign bank entry and foreign majority ownership on bank performance and firms' access to bank credit (Berger et al., 2005, Lin, 2011, Unite and Sullivan, 2003, Xu, 2011).

It is argued that the role of minority foreign ownership in the risk-taking behavior of a local bank is often ignored (Tacneng, 2015). This could be the case for emerging markets where the foreign ownership restrictions in the banking systems exist (Barth et al., 2001). However, there is a limited number of studies that have examined the role of minority foreign ownership on banking performance, such as banking efficiency in China (Berger et al., 2009a), bank risk in Egypt (ElBannan, 2015). This paper attempts to fill this gap by examining the impact of minority foreign ownership on bank risk in Vietnam.

Vietnam has taken various steps towards the liberalization and reform of the formal financial sector to improve the stability and performance of the Vietnamese banking system. Therefore, the banking sector has experienced significant institutional and structural changes over the past decades. Especially, foreign banks are also allowed to take a stake in local banks in the form of strategic partnerships. The government, however, imposes the condition that the total shares of foreign investors must not exceed $30 \%$ of the charter capital of a local bank. Additionally, the Vietnamese government considers further increasing foreign share in a local bank. This offers an interesting context to examine whether foreign ownership in local banks would reduce bank risk. This study is the first attempt to investigate the relationship between foreign ownership and bank insolvency risk in Vietnam. This would help Vietnamese authorities to decide on whether the total share of foreign investors should be increased. This will also increase the external validity of the impact of foreign ownership on bank risk in the South-East Asia region and others where the banking system has faced similar foreign capital restrictions although Tacneng (2015) may be one of the few exceptions.

Our findings show that foreign ownership is associated with a reduction in bank risk, implying that foreign banks can transfer knowledge and better managerial skills to local partners. Higher risk is related to greater technical efficiency, suggesting that the skimping-cost hypothesis may exist. The same conclusion is true for larger bank size, higher liquidity, and greater loan growth. In general, state-owned commercial banks are more stable than privately owned ones. This positive link still holds when observing the joint effect of government ownership and foreign acquisition. A positive relationship is also found in the case of listed banks with a greater level of foreign ownership.

The remainder of this study is structured as follows. Section 2 provides a brief overview of the Vietnamese banking system. Section 3 presents the literature review. Section 4 indicates 
LE Can foreign ownership reduce bank risk?

the methodology and data, and Section 5 discusses the empirical results while Section 6 concludes.

\section{An overview of the Vietnamese banking system}

Since the implementation of 'doi moi' (Renovation Reforms) in 1986, the banking system transformed the one-tier into a two-tier system. The State Bank of Vietnam (SBV) gradually shifted to more of a 'true' central bank and is responsible for controlling money, credit, and banking operation networks throughout the country to stabilize the value of money. Meanwhile, the SBV governs and supervises the second-tier system; the commercial banks include stateowned commercial banks (SOCBs), privately owned commercial banks (POCBs), joint-venture banks (JVBs), and foreign banks (FBs). Since then, several reforms were introduced to transform banks into market-functioning and improving banks' stability.

These reforms have mainly focused on restructuring SOCBs that have long served as a lending arm of state-owned enterprises (SOEs). The rest of the banking system, approximately $50 \%$ of total bank assets (KPMG, 2013) has a much-diversified structure. First, two policy banks have proven to be efficient tools of the state in mobilizing various resources, both domestically and internationally, to perform designated socio-political lending programs. Second, POCBs are generally the most market-oriented, and their equity ownership is mainly distributed among state, private, and foreign investors. Third, non-banking financial institutions (other credit institutions, investment banks, and financial auxiliaries) increase their contribution to the amount of credit available in the financial system. Last, the presence of foreign banks in the market has increased since Vietnam entered the World Trade Organization (WTO) in 2007. Two forms of foreign participation are greenfield investment and acquisitions of a minority share in the form of a strategic partnership. The liberalization process was further accelerated by entering the World Trade Organization (WTO) in 2007, The FBs' share of total commercial banking assets has remained small and stable, rising from $9.5 \%$ in 2007 to $10 \%$ in 2011 (WB, 2014). The government, however, imposes the condition that the total shares of foreign investors must not exceed $30 \%$ of the charter capital of a local bank. The further increase in the share of foreign banks in a local bank is considered in the restructuring program that was officially released by the Vietnamese government in 2012. This study is the first attempt to shed a light on whether or not foreign ownership reduces bank insolvency risk in the Vietnamese banking system.

\section{Literature review}

An increase in foreign shares in the banking sector has encouraged researchers to examine the role of foreign ownership in the host country. The benefits and costs of foreign ownership in 
the banking sector have documented in several studies ${ }^{1}$. Foreign ownership may (1) increase the credit supply and improve the allocation of this credit to domestic banks (2) improve the quality and availability of financial services due to improved competition (3) introduce better skills and technology (4) enhance banks' supervisory and legal framework (5) improve the access to the international capital market. Consequently, this strengthens the financial system (Giannetti and Ongena, 2009). In particular, as being a stakeholder of local banks, foreign banks transfer knowledge and superior technology to local banks. Therefore, this would increase the competitiveness of local banks (Choi and Hasan, 2005). The enhanced competition via the increasing entry of foreign banks may also reduce bank risk (Berger et al., 2005) and improve bank efficiency by reducing costs and improving profits (Claessens et al., 2001).

On the other hand, foreign banks may have lower performance than local banks. This can be explained by the fact that foreign banks may find it difficult to manage from a distance and deal with the different economic and regulatory environments (Berger et al., 2005). The presence of foreign banks may exert competitive pressure on domestic banks and reduce their franchise value or even may force them to increase their risk to address this competition (Hellmann et al., 2000).

The literature also demonstrates that bank risk is affected by the ownership structure (Demirgüç-Kunt et al., 1998, Barth et al., 2004, Angkinand and Wihlborg, 2010). There is no consensus on the impact of foreign ownership on bank risk. Several cross-country studies indicate that foreign ownership tends to reduce financial fragility and makes banks less prone to the financial crisis such as Laeven (1999) in East-Asia; Demirgüç-Kunt et al. (1998) in the global banking system; Barth et al. (2004) in 107 countries. In the same view, a negative relationship between foreign ownership and bank risk was also found in studies in individual countries such as Choi and Hasan (2005) in Korea; and Chou and Lin (2011) in Taiwan; and Tacneng (2015) in the Philippines. A study by ElBannan (2015) in Egypt posits that foreign ownership reduces bank credit risk but increases insolvency risk.

In contrast, several studies demonstrate the opposite findings. A cross-country study by Angkinand and Wihlborg (2010) suggests that foreign ownership is related to higher risktaking. A similar result has been found by Unite and Sullivan (2003) in the case of the Philippines. Furthermore, several studies show that foreign-owned banks are riskier than domestic banks such as Yeyati and Micco (2007) in Latin America; Fungáčová and Solanko (2009) in Russia. In the same vein, a cross-country study by De Nicolò and Loukoianova (2007) points out that foreign banks in non-industrialized countries bear a higher risk than local counterparts and this relationship depends on the country- and firm-specific characteristics. A study by Berger et al. (2005) demonstrates that the performance of foreign-owned banks in

\footnotetext{
${ }^{1}$ Bonin et al. (2005) provide an excellent review of the impact of foreign banks' entry on bank performance and efficiency in transition countries.
} 


\section{LE Can foreign ownership reduce bank risk?}

Argentina is somewhat lower than their domestically-owned counterpart, but the differences are small in relation to the effects of state ownership.

Because there are substantial differences in institutional reality and regulatory framework the experiences of one country do not necessarily reflect the true effect of foreign ownership in another country. By providing evidence on the relationship between foreign ownership and bank risk in Vietnam will strengthen the evidence of the impact of foreign ownership in emerging markets, especially the Asia-Pacific region.

\section{Methodology and data}

\subsection{Empirical model}

The primary goal of this paper is to examine the impact of foreign ownership and bank risk in Vietnam. Taking into account the extant literature as well as Vietnamese banks' characteristics, we consider both bank-specific and macroeconomic factors.

One is endogeneity: as an example, banks with poor management may fail to control operating costs, thus leading to higher risk. Higher-risk banks are also subject to more regulatory scrutiny - thus they may be required to hold a greater level of liquid assets and to be prudent to advance new lending. The causality could also go in the opposite direction as banks that face greater risk are required additional managerial efforts, additional resources to deal with these problems, which may ultimately reduce banks' efficiency. The ownership may be also endogenous as investors may choose to invest in banks with higher risk to maximize their expected utility (Gugler and Weigand, 2003).

Another critical issue is unobservable heterogeneity across banks, which could be very large in the Vietnamese case given differences in corporate governance, which cannot be wellmeasured. This is further confirmed by the results shown in Table 1. Finally, the bank risk may be persistent for Vietnamese banks because of political interference. ${ }^{2}$ This may be the case for state-owned commercial banks that are targeted to have lower insolvency risk.

We address three potential problems together by moving beyond the methodology currently as used in several papers on the relationship between foreign ownership and bank risk in emerging markets such as Tacneng (2015) in the Philippines and ElBannan (2015) in Egypt, mainly the pooled ordinary least square. Following prior studies such as García-Herrero et al. (2009), Lensink and Naaborg (2007), and among others, the Generalised Method of Moments (GMM) proposed by Arellano and Bover (1995) is used. This method accounts for endogeneity by using the lagged values of the dependent variable and the lagged value of other regressors

${ }^{2}$ Apart from the efforts of bank managers, the banking reforms proposed by the State Bank of Vietnam generally aim to improve the banks' stability over time. 
which are potentially suffering from endogeneity as instruments. We instrument for all regressors except for those which are exogenous. ${ }^{3}$ It is noted that the variables treated as endogenous in our models are presented in italics in the tables of results below. The GMM system also controls for unobserved heterogeneity and the persistence of the dependent variable. All in all, this estimator yields consistent estimations of the parameters. The estimated coefficients are also more efficient when the use of an ampler set of instruments is considered.

The last common challenge is the potential risk of omitted variables. Following the general to a specific procedure as used by García-Herrero et al. (2009), we estimate an equation with all possible regressors according to the suggestion of the extant literature and Vietnamese specific characteristics. Thereafter, a Wald test is run to test the joint hypothesis that the coefficients of the variables that are not significant individually are equal to zero. If not rejected, the model will be re-estimated with those control variables that show statistical significance in a general regression. Otherwise, we test a less restrictive hypothesis but still attempt to reduce the number of non-significant regressors to the maximum extent possible. A reduction in the number of regressors is stopped when we can reject that the remaining set of coefficients of the control variables is equal to zero. By doing so, the derived coefficients become more efficient since the number of regressors is decreased to the minimum.

In sum, along with data limitations, the system GMM is used to control for potential endogeneity as explained above, unobserved heterogeneity, and the persistence of the dependent variable, measuring bank risk. It is important to note that the nature of our sample with large $\mathrm{N}$ and small $\mathrm{T}$ does not allow the accurate estimation of $\mathrm{N}$-invariant regressors, mainly macroeconomic factors. When these macroeconomic variables are replaced by time dummies, the results are relatively similar and available upon request.

The above arguments suggest the application of a dynamic model that takes the following form:

$$
\begin{aligned}
\text { RISK }_{i, t}=\alpha_{0}+ & \alpha_{1} \text { RISK }_{i, t-1}+\alpha_{2} \text { FOR }_{i, t}+\alpha_{3} I N E F_{i, t}+\alpha_{4} L N T A_{i, t}+\alpha_{5} L A T A_{i, t} \\
& +\alpha_{6} L O G R_{i, t}+\alpha_{7} O W N E R_{i, t}+\alpha_{8} \text { LISTED }_{i, t}+\alpha_{9} H H I_{t}+\alpha_{10} G D P_{t} \\
& +\alpha_{11} I N F_{t}+\alpha_{12} \text { REF }_{t}+\varepsilon_{i, t}
\end{aligned}
$$

When calculating bank risk, there are few measures of bank risk such as the ratio of loan loss provision to total loans (Williams, 2004); the ratio of loan loss reserves (Altunbas et al., 2007, Le, 2018); the ratio of non-performing loans to total loans (Berger et al., 2009b), one or fiveyear expected default frequency (Fiordelisi et al., 2011) and the Z-score (Le, 2020a, Le et al., 2020, Le et al., 2019). The first three measures are subject to managerial discretion and capture

\footnotetext{
${ }^{3}$ It is assumed that strictly exogenous variables do not correlate with the individual effects while the endogenous variables are predetermined.
} 


\section{LE Can foreign ownership reduce bank risk?}

only credit risks. ${ }^{4}$ The expected default frequency requires data on stock prices, but many Vietnamese banks do not hold publicly traded securities. Subsequently, Z-score as a measure of bank risk is used as a dependent variable in our study. The Z-score is an inverse measure of overall bank risk. Additionally, equity to total assets (CAP) as a proxy for the bank's capitalization level is also used for robustness checks. A larger value of Z-score implies a greater bank's stability and less overall bank risk. Additionally, a higher value of CAP indicates lower bank risk.

Following Lepetit and Strobel (2013) and Le et al. (2019), a measure of Z-score is constructed as

$$
Z-\text { score }_{i, t}=\frac{\overline{R O A}_{i}+E Q U I T Y_{i, t}}{\sigma_{R O A_{i}}}
$$

where $\overline{R O A}_{i}$, the mean of ROA over the examined period; EQUITY, the ratio of total equity to total assets; $\sigma_{R O A}$, the standard deviation of ROA over the examined period. Because of a highly skewed distribution of Z-scores, the natural logarithm of Z-scores is used to reduce this problem. In brief, the natural logarithm of the Z-score is labeled as 'ZSCORE' in the rest of this research.

It is important to highlight that $F O R$, the total share of foreign banks in the local bank as a proxy for the effect of foreign ownership is our main interest variable. Furthermore, dummy variables are also used to evaluate the static, selection, and dynamic effects of foreign acquisitions on bank risk. These variables are further discussed in the next section. Foreign banks ${ }^{5}$ may transfer high technology, better managerial skills, and a wide range of good financial services to local partners - thus reducing banks' insolvency risk. Although local banks with foreign shareholdings have superior technical and financial resources, they may suffer from more severe information-asymmetry problems. These issues may arise due to the cultural differences between foreign and domestic shareholders. Therefore, foreign ownership may not improve banks' solvency. ${ }^{6}$

We also examine the effect of other bank ownership on bank risk-taking in Vietnam (stateowned vs privately owned commercial banks; listed vs non-listed banks). OWNER is a dummy variable that takes a value of 1 for a state-owned commercial bank, and 0 otherwise. LISTED is a dummy variable that takes a value of 1 for a listed bank, and 0 otherwise. In Vietnam,

${ }^{4}$ There is substantial missing data on non-performing loans of banks in the sample.

${ }^{5}$ It is important to notice the foreign stakes in local banks that are included in our sample are foreign banks.

${ }^{6}$ Tacneng (2015) provides a good discussion on the impact of foreign ownership on bank performance regarding foreign institutional or portfolio investors. 
foreign acquisition activities had undertaken either before or after listing in the stock market. Also, foreign banks were allowed to become strategic partners of domestic banks by purchasing shares up to $30 \%$ of total charter capital. Therefore, we include interaction terms between foreign acquisition and other bank ownership in our model to examine their joint effect on bank risk-taking.

For other bank-specific characteristics, we use bank efficiency (INEF), bank size (LNTA) liquidity (LATA), loan growth (LOGR) while market concentration (HHI), GDP growth (GDP), inflation $(I N F)$, and banking reform $(R E F)$ are used to control for macroeconomic conditions. More specifically, $I N E F^{7}$, technical inefficiency as derived from the bootstrap Data Envelopment Analysis is used to control for bank inefficiency. LNTA, the natural logarithm of total assets is used to control for bank size while bank liquidity (LATA) is proxied by the ratio of liquid assets to total assets. Similar to Le (2020a), loan growth (LOGR) is measured by the percentage change in the total loans from the year $\mathrm{t}-1$ to year $\mathrm{t}$. For macroeconomic factors, the Herfindahl-Hirschman Assets Index ( $H H I)$, the sum of squared relative market shares of total assets, is also used to provide robust checks for our main findings. The value of $\mathrm{HHI}$ ranges from 0 to 1 , where 0 indicates no concentration and 1 denotes a fully concentrated market. $G D P$, the annual growth rate of GDP is used to control for the economic condition that may affect a bank's investment opportunity and therefore bank risk-taking behavior while $I N F$, the inflation rate is used to control for the effects of inflation. In the Vietnamese banking system, this experienced the restructuring program to enhance bank stability that was officially announced in 2012 by the government. To account for this effect, $R E F$, a dummy variable that takes a value of 1 for the restructuring period (2011-2015), 0 otherwise is used.

Before selecting our model, we test for heteroscedasticity when one or more regressors are endogenous. Breusch and Pagan/Cook-Weisberg test is used to test the null hypothesis of homoscedasticity. We perform Breusch-Pagan/Cook-Weisberg heteroskedasticity tests $\chi$ in two steps. First, the equation with pooled OLS is run. Then, the Breusch-Pagan/Cook-Weisberg test is performed. The regression Chi-square $\left(\chi^{2}\right)$ results and their $p$-values are indicated in Table 2 (here only the results of $\chi^{2}$ and $p$-values are presented ${ }^{8}$ ). Table 1 shows the low p-values that demonstrate high heteroscedasticity, suggesting that the GMM method is preferable.

\footnotetext{
${ }^{7} \mathrm{INEF}$ is measured as $1-\hat{\hat{\theta}}_{D E A}$, where $\hat{\hat{\theta}}_{D E A}$ is the bias-corrected efficiency score under variable returns to scale assumption. Berger and Humphrey (1997) also suggest that the intermediation approach is more appropriate for measuring bank efficiency whereas the production approach is more suitable for measuring the efficiency of their branches. According to the intermediation approach in which banks act as intermediaries between depositors and borrowers, a 3x2 set of inputs and outputs are used. Following prior studies such as Le (2017), inputs include fixed assets, operating expenses, and loanable funds while outputs include loans and other earning assets.

${ }^{8}$ The full results of each equation can be provided upon request.
} 
LE Can foreign ownership reduce bank risk?

\subsection{Data}

Bank-specific information was primarily collected from annual reports of individual Vietnamese banks from 2006 to 2015 according to the Vietnamese accounting standards. Since Vietnam entered the World Trade Organisation in 2007, foreign banks have been allowed to acquire a certain amount of shares in the local banks. Only local banks are selected as they are main-active players while foreign bank affiliates and joint-venture banks are somewhat limited to operate in the Vietnamese markets 9 . Therefore, we obtain an unbalanced panel data of 40 banks that include five state-owned commercial banks and 35 privately owned commercial banks. These banks together accounted for more than $80 \%$ of total assets in the industry. Additionally, data on macroeconomic factors were collected from the World Bank Indicators (WB, 2017). Table 1 provides descriptive statistics of variables used in the system GMM estimator.

In this study, foreign ownership is also measured differently to reflect the special characteristics of the Vietnamese banking system. While a bank is in general considered foreign-owned if a foreign share is at least 50 of the capital in any local bank, such dummy would never have a value of 1 in the Vietnamese case because of restricted rules of foreign acquisition in the banking sector. Nonetheless, this does not mean that foreign ownership could not affect bank risk. To examine this effect, the actual foreign share in a local bank (FOR) is used. The mean of 0.053 suggests that foreign share accounts for $5.3 \%$ of the total capital of the average bank in Vietnam. This is relatively small compared to other countries, perhaps due to the imposition of a maximum foreign share of $30 \%$ in any local bank and the recent openness of the Vietnamese banking systems since 2007. For robustness check, we also use a dummy variable (AFOR) which takes a value of 1 for a year when the foreign acquisition was undertaken.

Following Berger et al. (2005), the static, selection and dynamic governance indicators are employed to examine the effects of foreign ownership. Due to the high correlation among these dummy variables as shown in Table 3 , three types of indicators are included in our model separately.

Table 1: The results of the Breusch-Pagan test

\begin{tabular}{|l||r|r|r|}
\hline & ZSCORE & AZSCORE & CAP \\
\hline \hline Chi-square $\left(\chi^{2}\right)$ & 112.54 & 341.58 & 504.19 \\
\cline { 2 - 4 }$P$-value & 0.00 & 0.00 & 0.00 \\
\hline
\end{tabular}

\footnotetext{
${ }^{9}$ This exclusion from the sample is necessary to ensure the homogeneity of the sample when estimating relative bank efficiency using the bootstrap DEA.
} 
Review of Economic Analysis 13 (2021) 479-500

Table 2: Descriptive statistics of variables used in this study

\begin{tabular}{|l||r|r|r|r|}
\hline & Mean & STD & Min & Max \\
\hline \hline ZSCORE & 2.968 & 0.623 & 0.995 & 5.483 \\
\hline AZSCORE & 2.956 & 0.659 & -0.725 & 5.479 \\
\hline CAP & 0.131 & 0.097 & 0.011 & 0.661 \\
\hline FOR & 0.053 & 0.077 & 0 & 0.3 \\
\hline AFOR & 0.344 & 0.476 & 0 & 1 \\
\hline NFOR & 0.171 & 0.377 & 0 & 1 \\
\hline SFOR & 0.408 & 0.492 & 0 & 1 \\
\hline DFOR & 0.309 & 0.463 & 0 & 1 \\
\hline INEF & 0.124 & 0.083 & 0.026 & 0.467 \\
\hline LNTA & 17.458 & 1.483 & 13.012 & 20.59 \\
\hline LATA & 0.35 & 0.142 & 0.041 & 0.816 \\
\hline LOGR & 0.523 & 1.103 & -0.407 & 11.317 \\
\hline OWNER & 0.142 & 0.349 & 0 & 1 \\
\hline LISTED & 0.182 & 0.386 & 0 & 1 \\
\hline HHI & 0.084 & 0.022 & 0.063 & 0.139 \\
\hline GDP & 0.061 & 0.006 & 0.052 & 0.071 \\
\hline INF & 0.104 & 0.07 & -0.002 & 0.227 \\
\hline REF & 0.474 & 0.5 & 0 & 1 \\
\hline No. Obs & 345 & 345 & 345 & 345 \\
\hline
\end{tabular}

Notes: ZSCORE, the sum of mean return on assets and the ratio of total equity to total assets, divided by the mean standard deviation of return on assets; AZSCORE, the sum of return on assets and the ratio of total equity to total assets, divided by the standard deviation of return on assets; CAP, the ratio of total equity to total assets; FOR, the share of foreign ownership in the local bank; AFOR, a dummy variable that takes a value of 1 for a year when foreign acquisition was undertaken; NFOR, a dummy variable that takes a value of 1 for a bank that maintains foreign ownership over the entire period and 0 for all periods for all other banks; SFOR, a dummy variable that takes a value of 1 for a bank that underwent at least one foreign acquisition over the entire period, and equals 1 or 0 for all periods for other banks; DFOR, a dummy variable that takes a value of 1 starting in the year following the foreign acquisition $(\mathrm{t}+1)$ and equals 0 prior to the bank's acquisition and for all years for banks that did not undergo a foreign acquisition; INEF, technical inefficiency score of a bank as obtained from the bootstrap DEA; LNTA, the natural logarithm of total assets; LOGR, the percentage change in the total loans from the year t-1 to year t; HHI, the Herfindahl-Hirschman Assets Index; GDP, the annual growth rate of GDP; INF, the inflation rate; REF, a dummy variable that takes a value of 1 for the restructuring period (2011-2015), and 0 otherwise. 


\section{LE Can foreign ownership reduce bank risk?}

The static indicator, foreign-owned banks with no governance change (NFOR) is a dummy indicating foreign-owned banks that did not change governance over the entire period. This variable equals 1 for all periods for a bank that maintains foreign ownership and 0 for all periods for all other banks. As shown, there appears $17.1 \%$ remained foreign-owned banks that had no governance change over the entire 2006-2015.

For the selection governance indicator, the selected for foreign acquisition (SFOR) is a dummy indicating banks that underwent one or more foreign acquisitions over the examined period. It is typically owners of bank organizations that do the 'selecting'. This selection variable equals 1 for all periods for a bank that had the corresponding governance change and 0 for all periods for all other banks. As shown, the number of institutions that were selected for the foreign acquisition was $40.8 \%$.

The dynamic governance indicator dummy variable, underwent foreign acquisition (DFOR) indicates the years following a bank's governance changes. A dummy equals 0 prior to the bank's governance change and 1 starting in the second year following the change. Following common practice in the bank merger and acquisition literature, we delete the observations in the year following foreign acquisition to help reduce some of the short-term transitional costs of consummating the governance change. These may include any one-time legal expenses, consultant fees, and severance pay, costs of changing or integrating the management and banking systems, and any costs involved in climbing the learning curves to understand the local economic environment of the acquired institution. Each dummy equals 0 for all periods for banks that did not undergo foreign acquisition. The mean of the dynamic indicator is often less than that for the corresponding selection indicator because the dynamic indicator only takes a value of 1 after the governance change. As indicated, the number of institutions that were selected for the dynamic foreign acquisition was $30.9 \%$.

Regarding other bank property, there appears that the number of state-owned commercial banks and listed banks were on average $14.2 \%$ and $18.2 \%$, respectively. The mean of 0.131 suggests that total equity accounted for $13.1 \%$ of the total assets of the average bank in Vietnam while the average Z-score of Vietnamese bank was 2.956. Additionally, a low standard deviation of bank-risk measures indicates slight volatility during the examined period. Other bank-specific variables indicate that the average bank inefficiency was $12.4 \%$; the average ratio of liquid assets to total assets was $35.1 \%$; the average loan growth was $52.3 \%$ with greater volatility (i.e. a standard deviation of 1.103). Also, the average annual GDP growth rate and the inflation rate were $6.1 \%$ and $10.4 \%$, respectively. The value of HHI was relatively low, indicating a competitive environment in the Vietnamese banking system.

Figure 1 shows an increasing trend of foreign acquisitions $(F O R)$ in local banks in the Vietnamese banking system. However, there appears an opposite phenomenon when observing bank capitalization (CAP) and bank stability (ZSCORE and AZSCORE) although they reached a peak in years the 2008-2009, respectively before deteriorating. 
Figure 1 The evolution of foreign share in domestic banks in Vietnam

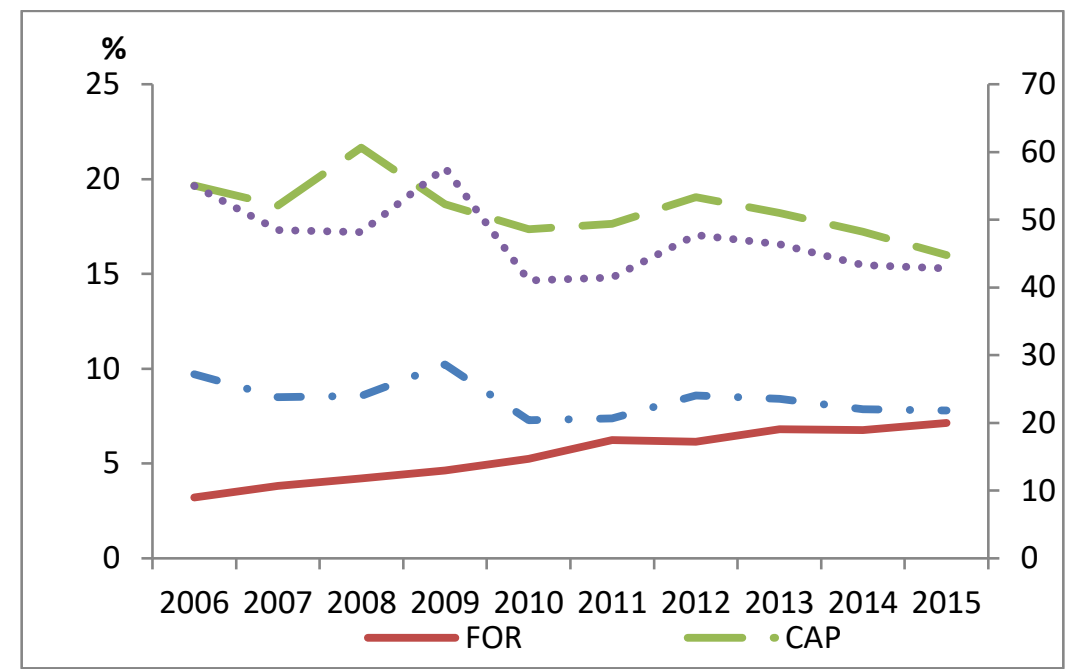

Note: The figures are estimated on average each year. FOR and $C A P$ are measured in percent.

\section{Results}

\subsection{The baseline models}

The results of the relationship between foreign ownership and bank risk in Vietnam between 2006 and 2015 are presented in Tables 2-3. To mitigate potential endogeneity with bank-level control variables, we follow Distinguin et al. (2013) by replacing all bank-level explanatory variables with their one-year lagged value in all regressions. Therefore, the one-year lagged values of the presumably endogenous variables will be used as instruments. ${ }^{10}$

The result of the Hansen test is also reported to investigate the validity of the dynamic panel model (Baltagi, 2008). Accordingly, as the $p$-value of the Hansen test is statistically not significant in any of the models, the null hypothesis cannot be rejected. ${ }^{11}$ Thus, there is no evidence of over-identifying restrictions. In other words, all conditions for the moments are satisfied and the above instruments are accepted. Moreover, the first- and second-order autocorrelation values are also reported between the first residual differences. In the first-order autocorrelation (AR1), the hypothesis of the non-existence of the first-order autocorrelation between first residual differences is rejected. However, this does not mean that estimates are

${ }^{10}$ More lags of these variables are not introduced in the regressions because they are weak instruments.

${ }^{11}$ Cameron and Pravin (2010) suggest that the value of the Hansen test for over-identifying restrictions should exceed 0.05 , thus the null hypothesis cannot be rejected. Alternatively, there is no correlation between the instrument variables and the residuals. 


\section{LE Can foreign ownership reduce bank risk?}

inconsistent. Inconsistency would be implied if the second-order autocorrelation is present (Arellano and Bond, 1991). The AR2 in all models shows that the moment conditions are satisfied since $p$-values are statistically not significant ${ }^{12}$. Nonetheless, this concludes that the estimated model meets diagnostic tests.

Table 3 The correlation matrix of variables used

\begin{tabular}{|l||rrrrrrrrrrrrrr|r|}
\hline & 1 & 2 & 3 & 4 & 5 & 6 & 7 & 8 & 9 & 10 & 11 & 12 & 13 & 14 & 15 \\
\hline \hline 1. ZSCORE & 1 & & & & & & & & & & & & & & \\
2. AZSCORE & 0.987 & 1 & & & & & & & & & & & \\
3. CAP & 0.319 & 0.322 & 1 & & & & & & & & & & & \\
4. FOR & 0.209 & 0.216 & 0.209 & 1 & & & & & & & & & & \\
5. AFOR & 0.173 & 0.177 & 0.223 & 0.952 & 1 & & & & & & & & & \\
6. NFOR & 0.045 & 0.038 & 0.173 & 0.571 & 0.626 & 1 & & & & & & & & \\
7. SFOR & 0.164 & 0.163 & 0.241 & 0.832 & 0.873 & 0.547 & 1 & & & & & & & \\
8. DFOR & 0.191 & 0.201 & 0.233 & 0.893 & 0.924 & 0.628 & 0.807 & 1 & & & & & & \\
9. INEF & 0.09 & 0.09 & -0.05 & 0.131 & 0.105 & 0.142 & 0.087 & 0.078 & 1 & & & & & \\
10. LNTA & -0.24 & -0.25 & -0.71 & 0.263 & 0.3 & 0.165 & 0.312 & 0.32 & -0.1 & 1 & & & & \\
11. LATA & -0.02 & -0.03 & -0.05 & 0.076 & 0.023 & -0.13 & 0.081 & 0.002 & -0.11 & -0.01 & 1 & & & \\
12. LOGR & -0.1 & -0.06 & -0.01 & -0.05 & -0.06 & -0 & -0.02 & -0.07 & -0.01 & -0.19 & 0.071 & 1 & & \\
13. GDP & 0.004 & 0.015 & 0.004 & -0.06 & -0.06 & 0.018 & 0.029 & -0.11 & -0.13 & -0.17 & -0 & 0.243 & 1 & \\
14. INF & 0.084 & 0.093 & 0.127 & -0.06 & -0.04 & -0.02 & -0.02 & -0.07 & 0.043 & -0.2 & 0.131 & -0.12 & -0.08 & 1 \\
15. HHI & 0.129 & 0.15 & 0.18 & -0.13 & -0.12 & 0.023 & 0.036 & -0.18 & 0.131 & -0.43 & -0.04 & 0.23 & 0.525 & -0.01 & 1 \\
\hline
\end{tabular}

Notes: ZSCORE, the sum of mean return on assets and the ratio of total equity to total assets, divided by the mean standard deviation of return on assets; AZSCORE, the sum of return on assets and the ratio of total equity to total assets, divided by the standard deviation of return on assets; CAP, the ratio of total equity to total assets; FOR, the share of foreign ownership in the local bank; AFOR, a dummy variable that takes a value of 1 for a year when foreign acquisition was undertaken; NFOR, a dummy variable that takes a value of 1 for a bank that maintains foreign ownership over the entire period and 0 for all periods for all other banks; SFOR, a dummy variable that takes a value of 1 for a bank that underwent at least one foreign acquisition over the entire period, and equals 1 or 0 for all periods for other banks; DFOR, a dummy variable that takes a value of 1 starting in the year following the foreign acquisition $(\mathrm{t}+1)$ and equals 0 prior to the bank's acquisition and for all years for banks that did not undergo a foreign acquisition; INEF, technical inefficiency score of a bank as obtained from the bootstrap DEA; LNTA, the natural logarithm of total assets; LOGR, the percentage change in the total loans from the year $\mathrm{t}-1$ to year $\mathrm{t}$; GDP, the annual economic growth rate; INF, the inflation rate; HHI, the Herfindahl-Hirschman Assets Index.

${ }^{12}$ Arellano and Bond (1991) demonstrate p-values of AR2 above 0.05 that instruments are still valid. 
Review of Economic Analysis 13 (2021) 479-500

Table 4 The relationship between foreign ownership and bank risk

\begin{tabular}{|c|c|c|c|c|c|c|c|}
\hline ZSCORE & (1) & (2) & (3) & (4) & (5) & (6) & (7) \\
\hline$\overline{Z S C O R E_{t-1}}$ & $\begin{array}{l}0.221 * * * \\
(0.059)\end{array}$ & $\begin{array}{l}0.216 * * * \\
(0.059)\end{array}$ & $\begin{array}{l}0.129 * \\
(0.07)\end{array}$ & $\begin{array}{l}0.186 * * \\
(0.076)\end{array}$ & $\begin{array}{l}0.221 * * * \\
(0.055)\end{array}$ & $\begin{array}{l}0.142 * * \\
(0.068)\end{array}$ & $\begin{array}{l}0.142 * * \\
(0.06)\end{array}$ \\
\hline FOR & $\begin{array}{l}2.117 * * * \\
(0.682)\end{array}$ & & & & & & \\
\hline$A F O R$ & & $\begin{array}{l}0.328 * * * \\
(0.097)\end{array}$ & $\begin{array}{l}0.282 \\
(0.175)\end{array}$ & & & & \\
\hline NFOR & & & & $\begin{array}{l}0.999 * * * \\
(0.289)\end{array}$ & & & \\
\hline SFOR & & & & & $\begin{array}{l}0.281 * * \\
(0.113)\end{array}$ & $\begin{array}{l}0.167 \\
(0.13)\end{array}$ & \\
\hline DFOR & & & & & & & $\begin{array}{l}0.056 \\
(0.067)\end{array}$ \\
\hline INEF & $\begin{array}{l}0.917 * * * \\
(0.338)\end{array}$ & $\begin{array}{l}0.878 * * \\
(0.347) \\
\end{array}$ & $\begin{array}{l}0.833 * * \\
(0.366)\end{array}$ & $\begin{array}{l}1.269 * * * \\
(0.309)\end{array}$ & $\begin{array}{l}0.79 * * * \\
(0.28)\end{array}$ & $\begin{array}{l}1.107 * * * \\
(0.368)\end{array}$ & $\begin{array}{l}0.949 * * * \\
(0.326)\end{array}$ \\
\hline LNTA & $\begin{array}{l}-0.128 * * \\
(0.053)\end{array}$ & $\begin{array}{l}-0.117 * * \\
(0.049)\end{array}$ & $\begin{array}{l}-0.145^{* * * *} \\
(0.053)\end{array}$ & $\begin{array}{l}-0.155^{* * * *} \\
(0.048)\end{array}$ & $\begin{array}{l}-0.08 \\
(0.051)\end{array}$ & $\begin{array}{l}-0.061 \\
(0.046)\end{array}$ & $\begin{array}{l}-0.086 \\
(0.052)\end{array}$ \\
\hline LATA & $\begin{array}{l}-0.886^{* * *} \\
(0.252)\end{array}$ & $\begin{array}{l}-0.806 * * * \\
(0.257)\end{array}$ & $\begin{array}{l}-0.924 * * * \\
(0.289)\end{array}$ & $\begin{array}{l}-0.653^{* * * *} \\
(0.2)\end{array}$ & $\begin{array}{l}-0.581^{* *} \\
(0.236)\end{array}$ & $\begin{array}{l}-0.573^{* *} \\
(0.255)\end{array}$ & $\begin{array}{l}-0.757 * * * \\
(0.243)\end{array}$ \\
\hline LOGR & $\begin{array}{l}-0.0002 \\
(0.0003)\end{array}$ & $\begin{array}{l}-0.0003 \\
(0.0003)\end{array}$ & $\begin{array}{l}-0.0004 \\
(0.0003)\end{array}$ & $\begin{array}{l}0.00003 \\
(0.0002)\end{array}$ & $\begin{array}{l}-0.0004 \\
(0.0003)\end{array}$ & $\begin{array}{l}-0.001^{*} \\
(0.0004)\end{array}$ & $\begin{array}{l}0.2+3) \\
-0.0002 \\
(0.243)\end{array}$ \\
\hline OWNER & $\begin{array}{l}0.885 * * * \\
(0.253)\end{array}$ & $\begin{array}{l}0.837 * * * \\
(0.26)\end{array}$ & $\begin{array}{l}1.091 * * * \\
(0.32)\end{array}$ & $\begin{array}{l}1.03 * * * \\
(0.233)\end{array}$ & $\begin{array}{l}0.825 * * * \\
(0.252)\end{array}$ & $\begin{array}{l}0.301 \\
(0.59)\end{array}$ & $\begin{array}{l}0.964 * * * \\
(0.264)\end{array}$ \\
\hline LISTED & $\begin{array}{l}-0.02 \\
(0.097)\end{array}$ & $\begin{array}{l}-0.046 \\
(0.093)\end{array}$ & $\begin{array}{l}0.12 \\
(0.127)\end{array}$ & $\begin{array}{l}0.051 \\
(0.095)\end{array}$ & $\begin{array}{l}0.054 \\
(0.082)\end{array}$ & $\begin{array}{l}0.423 \\
(0.296) \\
\end{array}$ & $\begin{array}{l}-0.061 \\
(0.089)\end{array}$ \\
\hline HHI & $\begin{array}{l}0.3 \\
(1.598)\end{array}$ & $\begin{array}{l}0.57 \\
(1.481)\end{array}$ & $\begin{array}{l}-0.12 \\
(1.609)\end{array}$ & $\begin{array}{l}-1.226 \\
(1.385)\end{array}$ & $\begin{array}{l}1.114 \\
(1.675)\end{array}$ & $\begin{array}{l}2.111 \\
(1.668)\end{array}$ & $\begin{array}{l}1.571 \\
(1.395)\end{array}$ \\
\hline GDP & $\begin{array}{l}0.642 \\
(2.359) \\
\end{array}$ & $\begin{array}{l}0.347 \\
(2.207)\end{array}$ & $\begin{array}{l}0.875 \\
(2.494) \\
\end{array}$ & $\begin{array}{l}0.678 \\
(1.803) \\
\end{array}$ & $\begin{array}{l}-1.65 \\
(2.106) \\
\end{array}$ & $\begin{array}{l}-0.523 \\
(2.435)\end{array}$ & $\begin{array}{l}-1.81 \\
(1.865) \\
\end{array}$ \\
\hline $\mathrm{INF}$ & $\begin{array}{l}0.385^{*} \\
(0.22)\end{array}$ & $\begin{array}{l}0.335 \\
(0.223)\end{array}$ & $\begin{array}{l}0.298 \\
(0.246)\end{array}$ & $\begin{array}{l}0.314^{*} \\
(0.149)\end{array}$ & $\begin{array}{l}0.299 \\
(0.228)\end{array}$ & $\begin{array}{l}0.26 \\
(0.242)\end{array}$ & $\begin{array}{l}0.448^{* * *} \\
(0.221)\end{array}$ \\
\hline REF & $\begin{array}{l}-0.024 \\
(0.036)\end{array}$ & $\begin{array}{l}-0.036 \\
(0.033)\end{array}$ & $\begin{array}{l}-0.062 \\
(0.041)\end{array}$ & $\begin{array}{l}0.02 \\
(0.032)\end{array}$ & $\begin{array}{l}-0.038 \\
(0.037)\end{array}$ & $\begin{array}{l}-0.043 \\
(0.038)\end{array}$ & $\begin{array}{l}-0.029 \\
0.033)\end{array}$ \\
\hline AFOR*OWNER & & & $\begin{array}{l}0.569 * * \\
(0.267)\end{array}$ & & & & \\
\hline AFOR*LISTED & & & $\begin{array}{l}-0.412 \\
(0.39)\end{array}$ & & & & \\
\hline SFOR*OWNER & & & & & & $\begin{array}{l}0.679 \\
(1.584) \\
\end{array}$ & \\
\hline SFOR*LISTED & & & & & & $\begin{array}{l}0.723^{* *} \\
(0.316)\end{array}$ & \\
\hline Constant & $\begin{array}{l}4.461 * * * \\
(0.978)\end{array}$ & $\begin{array}{l}4.28 * * * \\
(0.932) \\
\end{array}$ & $\begin{array}{l}5.11 * * * \\
(1.007) \\
\end{array}$ & $\begin{array}{l}4.881 * * * \\
(0.974)\end{array}$ & $\begin{array}{l}3.63 * * * \\
(0.974)\end{array}$ & $\begin{array}{l}3.45^{* * *} \\
(0.825)\end{array}$ & $\begin{array}{l}4.032 * * * \\
(1.027)\end{array}$ \\
\hline No. Obs & 305 & 305 & 305 & 305 & 305 & 305 & 305 \\
\hline No. Groups & 41 & 41 & 41 & 41 & 41 & 41 & 41 \\
\hline Hansen test (p-value) & 0.769 & 0.757 & 0.845 & 0.523 & 0.508 & 0.456 & 0.484 \\
\hline AR1 (p-value) & 0.003 & 0.005 & 0.011 & 0.003 & 0.004 & 0.004 & 0.005 \\
\hline AR2 (p-value) & 0.151 & 0.170 & 0.697 & 0.405 & 0.144 & 0.225 & 0.327 \\
\hline F-test & $124.18 * * *$ & $146.82 * * *$ & $44.28 * * *$ & $75.24 * * *$ & $49.45 * * *$ & $27.87 * * *$ & $455.58 * * *$ \\
\hline
\end{tabular}




\section{LE Can foreign ownership reduce bank risk?}

Notes: We only report the results of interaction terms among bank governance indicators that show statistical significance. The table contains the results estimated using the system GMM estimator. Variables in italics are instrumented through the GMM procedure following Arellano and Bover (1995). Standard errors are shown in parentheses. *,**,***Significant at 10,5 , and 1 percent levels, respectively.

The data in Table 4 shows that the coefficients of foreign ownership measures are generally positive and significant in most of all models, ${ }^{13}$ suggesting that foreign ownership can reduce bank risk. In other words, foreign banks can transfer knowledge and better managerial skills to local partners. This is in line with those by ElBannan (2015) in Egypt; Tacneng (2015) in the Philippines. In the case of the Vietnamese banking system, Le (2020b) emphasizes that foreignowned banks may have an advantage of paying lower interest rates than their local counterparts as they are considered less risky, possibly due to their diversified loan portfolio. Also, Le (2021) further demonstrates that foreign ownership can improve bank stability when pursuing geographic expansion and income diversification. When observing other bank ownership, OWNER is in general positively associated with ZSCORE, suggesting that POCBs are less stable than SOCBs. Due to the advantage of government ownership, they are often perceived as safe banks. Therefore, they are allowed to pay their depositors lower interest rates, which in turn improving their profitability and reducing their risk (Le et al., 2019). This positive link is the same when observing the joint effect of foreign ownership (AFOR) and government ownership (OWNER). This further supports foreign acquisition activities in state-owned banks.

Although no evidence that listed banks (LISTED) are more stable than non-listed ones, this relationship becomes positive when taking into account the effect of foreign ownership (SFOR*LISTED). This further encourages banks to be listed in the Vietnamese stock market together with further foreign acquisition activities. Therefore, this would help the Vietnamese banking system become more transparent.

For bank-specific characteristics, INEF is positively and significantly associated with ZSCORE in all versions, thus supporting the skimping costs hypothesis. This is in line with those by Le (2018) who suggests that banks tend to skimp on operating costs by reducing credit monitoring, collateral valuing, and market activities to achieve short-run economic efficiency. These activities, however, would deteriorate loan quality, thus resulting in a higher risk. The negative impact of LNTA on ZSCORE indicates that large banks have more incentives to invest more in risky assets because of the too-big-to-fail effects. This finding is comparable with those of Le (2021). The coefficient of LATA is negative and significant in all models, suggesting that liquid banks are more risk-taking. This can be explained by the fact that banks with a higher

${ }^{13}$ The coefficients of DFOR in all models are statistically not significant. This interpretation should be cautious because of small observations on this dummy variable. 
level of liquid assets will not be profitable since liquid assets do not generate a high yield. Consequently, they may face greater risk (Delis and Staikouras, 2011). Furthermore, a negative relationship between LOGR and ZSCORE argues that excessive lending results in higher bank risk. The accelerating pace of lending between 2007 and 2011, especially advancing to nondeposit sources, potentially exposed the Vietnamese banking sector to higher liquidity risk. This result supports the earlier findings of Le (2018) who found that significant credit expansions do not generate corresponding increases in bank safety margins.

Lastly, Table 4 indicates that the coefficients of macroeconomic factors are statistically not significant except for $I N F$, suggesting there is no evidence that bank risk in Vietnam is affected by macroeconomic conditions. A positive relationship between INF and ZSCORE suggests that inflation may be fully anticipated and Vietnamese banks may adjust their interest rate accurately. Therefore, banks may generate greater profitability and improve their stability.

\subsection{Robustness checks}

We run several robustness checks on our main models and for the ease of interpretation, our main interest variables regarding bank property are only focused on. It may be argued the lack of consistent evidence on the relationship between foreign ownership and bank risk depends upon the measures that are used for bank risk (Boyd and De Nicolo, 2005). Hence, we use different measures of bank risk: an alternative measure of Z-score and bank capitalization ${ }^{14}$. Following Laeven and Levine (2009), Fu et al. (2015), and Cihák and Hesse (2007) and Le et al. (2019) the Z-score of a bank is measured as

$$
Z-\text { score }_{i, t}=\frac{R O A_{i, t}+E Q U I T Y_{i, t}}{\sigma_{R O A_{i}}}
$$

where ROA, return on assets; EQUITY, the ratio of total equity to total assets; $\sigma_{R O A}$, the standard deviation of ROA that is calculated based on the observations of ROA over the examined period.

Table 5 shows the coefficients of foreign ownership measures are generally positive. When observing the interaction terms, the joint effect of foreign acquisition and government ownership on bank stability is still positive. The same results are true to the case of the banking capitalization level as a dependent variable as indicated in Table 6. Nonetheless, our main findings as above are confirmed.

\footnotetext{
${ }^{14} \mathrm{We}$ also use and the ratio of loan loss reverse to total assets to control for credit risk (Le, 2018). The coefficients of foreign ownership measures are generally negative but statistically not significant, thus our main findings are robust.
} 
LE Can foreign ownership reduce bank risk?

Table 5 The impact of foreign ownership on the bank risk using an alternative measure

\begin{tabular}{|c|c|c|c|c|c|c|}
\hline AZSCORE & (1) & (2) & (3) & (4) & (5) & (6) \\
\hline$A Z S C O R E_{t-1}$ & $\begin{array}{l}0.273 * * * \\
(0.068)\end{array}$ & $\begin{array}{l}0.305 * * * \\
(0.072)\end{array}$ & $\begin{array}{l}0.101^{*} \\
(0.05)\end{array}$ & $\begin{array}{l}0.246^{* * * *} \\
(0.058)\end{array}$ & $\begin{array}{l}0.137 * * * \\
(0.049)\end{array}$ & $\begin{array}{l}0.323 * * * \\
(0.067)\end{array}$ \\
\hline FOR & $\begin{array}{l}1.374 * \\
(0.707)\end{array}$ & & & & & \\
\hline$A F O R$ & & $\begin{array}{l}0.215 * * \\
(0.087) \\
\end{array}$ & & & & \\
\hline NFOR & & & $\begin{array}{l}1.358 * * * \\
0.225) \\
\end{array}$ & & & \\
\hline SFOR & & & & $\begin{array}{l}0.898 * * * \\
(0.161)\end{array}$ & $\begin{array}{l}0.483^{* *} \\
(0.182)\end{array}$ & \\
\hline DFOR & & & & & & $\begin{array}{l}0.205^{* * *} \\
(0.07)\end{array}$ \\
\hline$I N E F$ & $\begin{array}{l}0.785 \\
(0.568) \\
\end{array}$ & $\begin{array}{l}0.711 \\
(0.547) \\
\end{array}$ & $\begin{array}{l}1.387 * * * \\
(0.322) \\
\end{array}$ & $\begin{array}{l}1.685 * * * \\
(0.38)\end{array}$ & $\begin{array}{l}1.088 * * * \\
(0.313) \\
\end{array}$ & $\begin{array}{l}0.577 \\
(0.543) \\
\end{array}$ \\
\hline LNTA & $\begin{array}{l}-0.307 * * * \\
(0.082)\end{array}$ & $\begin{array}{l}-0.287 * * * \\
(0.081)\end{array}$ & $\begin{array}{l}-0.225^{* * *} \\
(0.051)\end{array}$ & $\begin{array}{l}-0.29 * * * \\
(0.051)\end{array}$ & $\begin{array}{l}-0.111 * * \\
(0.051)\end{array}$ & $\begin{array}{l}-0.333 * * * \\
(0.087)\end{array}$ \\
\hline LATA & $\begin{array}{l}-0.724 * * \\
(0.29) \\
\end{array}$ & $\begin{array}{l}-0.659 * * \\
(0.32)\end{array}$ & $\begin{array}{l}-0.399 * \\
(0.233) \\
\end{array}$ & $\begin{array}{l}-1.482 * * * \\
(0.261)\end{array}$ & $\begin{array}{l}-0.648 * * * \\
(0.198)\end{array}$ & $\begin{array}{l}-0.359 \\
(0.298) \\
\end{array}$ \\
\hline LOGR & $\begin{array}{l}-0.001 \\
(0.001)\end{array}$ & $\begin{array}{l}-0.001 \\
(0.001) \\
\end{array}$ & $\begin{array}{l}0.0001 \\
(0.0003)\end{array}$ & $\begin{array}{l}-0.001^{*} \\
(0.0003) \\
\end{array}$ & $\begin{array}{l}-0.0004 * \\
(0.0002) \\
\end{array}$ & $\begin{array}{l}-0.001 \\
(0.001) \\
\end{array}$ \\
\hline OWNER & $\begin{array}{l}1.259 * * * \\
(0.29)\end{array}$ & $\begin{array}{l}1.063 * * * \\
(0.262)\end{array}$ & $\begin{array}{l}1.452 * * * \\
(0.249)\end{array}$ & $\begin{array}{l}1.103 * * * \\
(0.278)\end{array}$ & $\begin{array}{l}0.269 \\
(0.654) \\
\end{array}$ & $\begin{array}{l}1.366 * * * \\
(0.281)\end{array}$ \\
\hline LISTED & $\begin{array}{l}0.117 \\
(0.111)\end{array}$ & $\begin{array}{l}0.085 \\
(0.108)\end{array}$ & $\begin{array}{l}0.119 \\
(0.112)\end{array}$ & $\begin{array}{l}-0.028 \\
(0.084) \\
\end{array}$ & $\begin{array}{l}-0.346 \\
(0.219)\end{array}$ & $\begin{array}{l}0.086 \\
(0.1)\end{array}$ \\
\hline$H H I$ & $\begin{array}{l}-3.933 \\
(2.387)\end{array}$ & $\begin{array}{l}-3.495 \\
(2.344)\end{array}$ & $\begin{array}{l}-2.518 * \\
(1.417)\end{array}$ & $\begin{array}{l}-5.509 * * * \\
(1.327)\end{array}$ & $\begin{array}{l}-1.024 \\
(2.161)\end{array}$ & $\begin{array}{l}-4.587 * \\
(2.444) \\
\end{array}$ \\
\hline GDP & $\begin{array}{l}5.639 * \\
(3.059) \\
\end{array}$ & $\begin{array}{l}5.601 * \\
(2.788) \\
\end{array}$ & $\begin{array}{l}0.809 \\
(1.967)\end{array}$ & $\begin{array}{l}5.291 * * * \\
(1.173)\end{array}$ & $\begin{array}{l}-2.297 \\
(1.892) \\
\end{array}$ & $\begin{array}{l}\text { 6.158** } \\
(2.664) \\
\end{array}$ \\
\hline INF & $\begin{array}{l}-0.032 \\
(0.312) \\
\end{array}$ & $\begin{array}{l}-0.139 \\
(0.333) \\
\end{array}$ & $\begin{array}{l}0.225 \\
(0.18) \\
\end{array}$ & $\begin{array}{l}-0.106 \\
(0.227) \\
\end{array}$ & $\begin{array}{l}0.322 \\
(0.222) \\
\end{array}$ & $\begin{array}{l}-0.19 \\
(0.305) \\
\end{array}$ \\
\hline REF & $\begin{array}{l}0.0001 \\
(0.058) \\
\end{array}$ & $\begin{array}{l}-0.008 \\
(0.056) \\
\end{array}$ & $\begin{array}{l}0.003 \\
(0.036) \\
\end{array}$ & $\begin{array}{l}0.032 \\
(0.034)\end{array}$ & $\begin{array}{l}-0.06 \\
(0.047) \\
\end{array}$ & $\begin{array}{l}0.027 \\
(0.059) \\
\end{array}$ \\
\hline SFOR*OWNER & & & & & $\begin{array}{l}2.348 * \\
(1.277)\end{array}$ & \\
\hline SFOR*LISTED & & & & & $\begin{array}{l}0.101 \\
(0.281)\end{array}$ & \\
\hline Constant & $\begin{array}{l}7.455 * * * \\
(1.594) \\
\end{array}$ & $\begin{array}{l}7.042 * * * \\
(1.62) \\
\end{array}$ & $\begin{array}{l}6.25 * * * \\
(0.93) \\
\end{array}$ & $\begin{array}{l}7.313 * * * \\
(1.088)\end{array}$ & $\begin{array}{l}4.581 * * * \\
(0.966)\end{array}$ & $\begin{array}{l}7.69 * * * \\
(1.674)\end{array}$ \\
\hline No. Obs & 305 & 305 & 305 & 305 & 305 & 305 \\
\hline No. Groups & 41 & 41 & 41 & 41 & 41 & 41 \\
\hline $\begin{array}{l}\text { Hansen test (p- } \\
\text { value) }\end{array}$ & 0.587 & 0.619 & 0.577 & 0.630 & 0.573 & 0.419 \\
\hline AR1 (p-value) & 0.144 & 0.144 & 0.137 & 0.096 & 0.123 & 0.128 \\
\hline AR2 (p-value) & 0.345 & 0.312 & 0.605 & 0.907 & 0.343 & 0.206 \\
\hline F-test & $30.54 * * *$ & $28.82 * * *$ & $68.35 * * *$ & $56.42 * * *$ & $612.90 * * *$ & $26.13 * * *$ \\
\hline
\end{tabular}

Notes: See table 4. 
Review of Economic Analysis 13 (2021) 479-500

Table 6 The impact of foreign ownership on bank capitalizatio

\begin{tabular}{|c|c|c|c|c|c|c|}
\hline CAP & (1) & (2) & (3) & (5) & (6) & (7) \\
\hline$C A P_{t-1}$ & $\begin{array}{l}0.135 * * * \\
(0.032) \\
\end{array}$ & $\begin{array}{l}0.101 * * * \\
(0.025) \\
\end{array}$ & $\begin{array}{l}0.159 * * * \\
(0.042)\end{array}$ & $\begin{array}{l}0.188 * * * \\
(0.052) \\
\end{array}$ & $\begin{array}{l}0.213 * * * \\
(0.065) \\
\end{array}$ & $\begin{array}{l}0.135 * * * \\
(0.045) \\
\end{array}$ \\
\hline FOR & $\begin{array}{l}0.167 * * * \\
(0.039)\end{array}$ & $\begin{array}{l}0.119 * * * \\
(0.041)\end{array}$ & & & & \\
\hline$A F O R$ & & & $\begin{array}{l}0.033 * * * \\
(0.006)\end{array}$ & & & \\
\hline NFOR & & & & $\begin{array}{l}0.046^{*} \\
(0.024)\end{array}$ & & \\
\hline SFOR & & & & & $\begin{array}{l}0.048 * * \\
(0.023) \\
\end{array}$ & \\
\hline DFOR & & & & & & $\begin{array}{l}0.004 \\
(0.009) \\
\end{array}$ \\
\hline$I N E F$ & $\begin{array}{l}0.112 * * * \\
(0.028)\end{array}$ & $\begin{array}{l}0.077 * * * \\
(0.026)\end{array}$ & $\begin{array}{l}0.108 * * * \\
(0.024)\end{array}$ & $\begin{array}{l}0.033 \\
(0.035)\end{array}$ & $\begin{array}{l}0.066^{*} \\
(0.037)\end{array}$ & $\begin{array}{l}0.012 \\
(0.035)\end{array}$ \\
\hline LNTA & $\begin{array}{l}-0.038 * * * \\
(0.006) \\
\end{array}$ & $\begin{array}{l}-0.038 * * * \\
(0.006) \\
\end{array}$ & $\begin{array}{l}-0.037 * * * \\
(0.006) \\
\end{array}$ & $\begin{array}{l}-0.037 * * * \\
(0.006)\end{array}$ & $\begin{array}{l}-0.042 * * * \\
(0.009)\end{array}$ & $\begin{array}{l}-0.034 * * * \\
(0.006)\end{array}$ \\
\hline LATA & $\begin{array}{l}-0.105 * * * \\
(0.02)\end{array}$ & $\begin{array}{l}-0.093 * * * \\
(0.021)\end{array}$ & $\begin{array}{l}-0.087 * * * \\
(0.017)\end{array}$ & $\begin{array}{l}-0.051 \\
(0.031) \\
\end{array}$ & $\begin{array}{l}-0.197 * * * \\
(0.028)\end{array}$ & $\begin{array}{l}-0.071^{* *} \\
(0.03)\end{array}$ \\
\hline LOGR & $\begin{array}{l}-0.0001 * * * \\
(0.00002)\end{array}$ & $\begin{array}{l}-0.0001 * * * \\
(0.00002)\end{array}$ & $\begin{array}{l}-0.0001 * * * \\
(0.00002)\end{array}$ & $\begin{array}{l}-0.0001 * * * \\
(0.00004)\end{array}$ & $\begin{array}{l}-0.00004 \\
(0.00002)\end{array}$ & $\begin{array}{l}-0.0001 * * * \\
(0.00004)\end{array}$ \\
\hline OWNER & $\begin{array}{l}0.032 \\
(0.026) \\
\end{array}$ & $\begin{array}{l}0.019 \\
(0.029) \\
\end{array}$ & $\begin{array}{l}0.03 \\
(0.026) \\
\end{array}$ & $\begin{array}{l}0.011 \\
(0.026) \\
\end{array}$ & $\begin{array}{l}-0.01 \\
(0.025) \\
\end{array}$ & $\begin{array}{l}-0.006 \\
(0.029) \\
\end{array}$ \\
\hline LISTED & $\begin{array}{l}-0.007 \\
(0.008) \\
\end{array}$ & $\begin{array}{l}-0.002 \\
(0.009) \\
\end{array}$ & $\begin{array}{l}-0.008 \\
(0.008) \\
\end{array}$ & $\begin{array}{l}0.02 * \\
(0.011) \\
\end{array}$ & $\begin{array}{l}-0.004 \\
(0.011) \\
\end{array}$ & $\begin{array}{l}0.006 \\
(0.011) \\
\end{array}$ \\
\hline$H H I$ & $\begin{array}{l}-0.317 \\
(0.112) \\
\end{array}$ & $\begin{array}{l}-0.255^{*} \\
(0.141) \\
\end{array}$ & $\begin{array}{l}-0.316 * * \\
(0.124) \\
\end{array}$ & $\begin{array}{l}-0.148 \\
(0.148) \\
\end{array}$ & $\begin{array}{l}-0.292 \\
(0.184) \\
\end{array}$ & $\begin{array}{l}-0.08 \\
(0.142) \\
\end{array}$ \\
\hline GDP & $\begin{array}{l}-0.196 \\
(0.141) \\
\end{array}$ & $\begin{array}{l}-0.213 \\
(0.193) \\
\end{array}$ & $\begin{array}{l}-0.118 \\
(0.166) \\
\end{array}$ & $\begin{array}{l}-0.28 \\
(0.198) \\
\end{array}$ & $\begin{array}{l}0.105 \\
(0.175)\end{array}$ & $\begin{array}{l}-0.358 * * \\
(0.172)\end{array}$ \\
\hline INF & $\begin{array}{l}-0.009 \\
(0.016) \\
\end{array}$ & $\begin{array}{l}-0.033^{*} \\
(0.016) \\
\end{array}$ & $\begin{array}{l}-0.013 \\
(0.017) \\
\end{array}$ & $\begin{array}{l}-0.048 * * * \\
(0.018)\end{array}$ & $\begin{array}{l}0.004 \\
(0.019) \\
\end{array}$ & $\begin{array}{l}-0.034 * \\
(0.019) \\
\end{array}$ \\
\hline REF & $\begin{array}{l}0.01 * * * \\
(0.003) \\
\end{array}$ & $\begin{array}{l}0.0002 \\
(0.004) \\
\end{array}$ & $\begin{array}{l}0.008 * * * \\
(0.003)\end{array}$ & $\begin{array}{l}0.011 * * \\
(0.004) \\
\end{array}$ & $\begin{array}{l}0.019 * * * \\
(0.005)\end{array}$ & $\begin{array}{l}0.006 \\
(0.004) \\
\end{array}$ \\
\hline FOR*OWNER & & $\begin{array}{l}0.618 * * \\
(0.255) \\
\end{array}$ & & & & \\
\hline FOR*LISTED & & $\begin{array}{l}-0.135 \\
(0.164) \\
\end{array}$ & & & & \\
\hline Constant & $\begin{array}{l}0.838 * * * \\
(0.097) \\
\end{array}$ & $\begin{array}{l}0.855 * * * \\
(0.115) \\
\end{array}$ & $\begin{array}{l}0.802 * * * \\
(0.103) \\
\end{array}$ & $\begin{array}{l}0.801 * * * \\
(0.115) \\
\end{array}$ & $\begin{array}{l}0.89 * * * \\
(0.169) \\
\end{array}$ & $\begin{array}{l}0.772 * * * \\
(0.106) \\
\end{array}$ \\
\hline No. Obs & 305 & 305 & 305 & 305 & 305 & 305 \\
\hline No. Groups & 41 & 41 & 41 & 41 & 41 & 41 \\
\hline Hansen test (p-value) & 0.724 & 0.724 & 0.734 & 0.656 & 0.409 & 0.484 \\
\hline AR1 (p-value) & 0.022 & 0.024 & 0.021 & 0.016 & 0.006 & 0.018 \\
\hline AR2 (p-value) & 0.117 & 0.131 & 0.093 & 0.06 & 0.078 & 0.076 \\
\hline F-test & $108.2 * * *$ & $185.53 * * *$ & $68.35 * * *$ & $31.34 * * *$ & $56.57 * * *$ & $51.70 * * *$ \\
\hline
\end{tabular}

Notes: See table 4. 
LE Can foreign ownership reduce bank risk?

\section{Conclusion}

This study investigated the impact of foreign ownership on bank risk between 2006 and 2015 in Vietnam. Our findings show that foreign ownership is associated with a reduction in bank risk, suggesting that further removal of restrictions on foreign investments in the banking system should be considered. The findings also indicate that higher bank risk is related to greater technical efficiency, suggesting that supervisors must pay special attention to the bank's internal credit control procedures (i.e. loan monitoring and review, collateral valuing). The same finding is true for large banks, for banks with higher liquid assets, and banks with greater loan growth. Furthermore, state-owned banks are generally more stable than privately owned ones. The greater stability is more associated with either state-owned banks or listed banks with a higher level of foreign acquisition. Along with further promoting foreign acquisition in the banking system, banks should be encouraged to list in the stock market in order to enhance transparency.

This study may suffer the following limitation. Our research only studies one country within a limited period, suggesting that future research needs to examine the relationship between foreign ownership and bank performance in other emerging markets, especially the Asia-Pacific region that have an analogous banking structure for robust checks.

\section{References}

Altunbas, Yener, Santiago Carbo, Edward P. M. Gardener and Philip Molyneux (2007), Examining the relationships between capital, risk and efficiency in European banking, European Financial Management, 13, 49-70.

Angkinand, Apanard and Clas Wihlborg (2010), Deposit insurance coverage, ownership, and banks' risk-taking in emerging markets, Journal of International Money and Finance, 29, 252-274.

Arellano, Manuel and Stephen Bond (1991), Some tests of specification for panel data: Monte Carlo evidence and an application to employment equations, The Review of Economic Studies, 58, 277-297.

Arellano, Manuel and Olympia Bover (1995), Another look at the instrumental variable estimation of error-components models, Journal of Econometrics, 68, 29-51.

Baltagi, Badi H (2008), Econometric analysis of panel data. New York: John Wiley.

Barth, James R., Gerard Caprio and Ross Levine (2004), Bank regulation and supervision: what works best?, Journal of Financial Intermediation, 13, 205-248.

Berger, Allen N, George RG Clarke, Robert Cull, Leora Klapper and Gregory F Udell (2005), Corporate governance and bank performance: A joint analysis of the static, selection, and dynamic effects of domestic, foreign, and state ownership, Journal of Banking \& Finance, 29, 2179-2221. 
Berger, Allen N and David B Humphrey (1997), Efficiency of financial institutions: International survey and directions for future research, European journal of operational research, 98, 175-212.

Berger, Allen N., Iftekhar Hasan and Mingming Zhou (2009a), Bank ownership and efficiency in China: What will happen in the world's largest nation?, Journal of Banking \& Finance, 33, 113-130.

Berger, Allen N., Leora F. Klapper and Rima Turk-Ariss (2009b), Bank competition and financial stability, Journal of Financial Services Research, 35, 99-118.

Bonin, John P, Iftekhar Hasan and Paul Wachtel (2005), Bank performance, efficiency and ownership in transition countries, Journal of Banking \& Finance, 29, 31-53.

Boyd, John H and Gianni De Nicolo (2005), The theory of bank risk taking and competition revisited, The Journal of Finance, 60, 1329-1343.

Choi, Sungho and Iftekhar Hasan (2005), Ownership, governance, and bank performance: Korean experience, Financial markets, institutions \& instruments, 14, 215-242.

Chou, Shuching and Fengyi Lin (2011), Bank's risk-taking and ownership structure-evidence for economics in transition stage, Applied Economics, 43, 1551-1564.

Claessens, Stijn, Aslı Demirgüç-Kunt and Harry Huizinga (2001), How does foreign entry affect domestic banking markets?, Journal of Banking \& Finance, 25, 891-911.

Claessens, Stijn and Neeltje Horen (2014), Foreign banks: Trends and impact, Journal of Money, Credit and Banking, 46, 295-326.

Crystal, Jennifer S, B Gerard Dages and Linda S Goldberg (2002), Has foreign bank entry led to sounder banks in Latin America?, Current Issues in Economics and Finance, 8, 1-6.

Delis, Manthos D and Panagiotis K Staikouras (2011), Supervisory effectiveness and bank risk, Review of Finance, 15, 511-543.

Demirgüç-Kunt, A, Ross Levine and Hong-Ghi Min (1998), Opening to foreign banks: Issues of stability, efficiency, and growth, in S. Lee (eds.), The implications of globalization of World financial markets. Soul: The Bank of Korea.

Distinguin, Isabelle, Caroline Roulet and Amine Tarazi (2013), Bank regulatory capital and liquidity: Evidence from US and European publicly traded banks, Journal of Banking \& Finance, 37, 3295-3317.

ElBannan, Mona A (2015), Do consolidation and foreign ownership affect bank risk taking in an emerging economy? An empirical investigation, Managerial Finance, 41, 874-907.

Fiordelisi, Franco, David Marques-Ibanez and Phil Molyneux (2011), Efficiency and risk in European banking, Journal of Banking \& Finance, 35, 1315-1326.

$\mathrm{Fu}$, Xiaoqing Maggie, Yongjia Rebecca Lin and Philip Molyneux (2015), Bank capital and liquidity creation in Asia Pacific, Economic Inquiry, 54, 966-993. 
LE Can foreign ownership reduce bank risk?

Fungáčová, Zuzana and Laura Solanko (2009), Risk-taking by Russian banks: Do location, ownership and size matter?, in M Balling (eds.), Current trends in the Russian financial system. Vienna: The European Money and Finance Forum.

García-Herrero, Alicia, Sergio Gavilá and Daniel Santabárbara (2009), What explains the low profitability of Chinese banks?, Journal of Banking \& Finance, 33, 2080-2092.

Giannetti, Mariassunta and Steven Ongena (2009), Financial integration and firm performance: Evidence from foreign bank entry in emerging markets, Review of Finance, 13, 181-223.

Gianni De Nicolò and Elena Loukoianova (2007), Bank ownership, market structure and risk, IMF Working Paper No. 07/215

Gugler, Klaus and Jürgen Weigand (2003), Is ownership really endogenous?, Applied Economics Letters, 10, 483-486.

Hellmann, Thomas F., Kevin C. Murdock and Joseph E. Stiglitz (2000), Liberalization, moral hazard in banking, and prudential regulation: Are capital requirements enough?, The American Economic Review, 90, 147-165.

James R. Barth, Gerard Caprio and Ross Levine (2001), The regulation and supervision of banks around the world: A new database, World Bank Policy Research Working Paper No. 2588

KPMG (2013), Vietnam banking survey 2013. Ho Chi Minh city: KPMG.

Laeven, Luc and Ross Levine (2009), Bank governance, regulation and risk taking, Journal of Financial Economics, 93, 259-275.

Le, Tu D.Q. (2017), The efficiency effects of bank mergers: An analysis of case studies in Vietnam, Risk Governance \& Control, 7, 61-70.

..(2018), Bank risk, capitalisation and technical efficiency in the Vietnamese banking system, Australasian Accounting Business \& Finance Journal, 12, 42-61.

.......... (2020a), The interrelationship among bank profitability, bank stability, and loan growth: Evidence from Vietnam, Cogent Business \& Management, 7, 1-18.

............ (2020b), Market discipline and the regulatory change: Evidence from Vietnam, Cogent Economics \& Finance, 8, 1-12.

........... (2021), Geographic expansion, income diversification, and bank stability: Evidence from Vietnam, Cogent Business \& Management, 8, 1-23.

Le, Tu D.Q., Van T.H. Nguyen and Son H. Tran (2020), Geographic loan diversification and bank risk: A cross-country analysis, Cogent Economics \& Finance, 8, 1-20.

Le, Tu D.Q., Son H. Tran and Liem T. Nguyen (2019), The impact of multimarket contacts on bank stability in Vietnam, Pacific Accounting Review, 31, 336-357.

Lensink, Robert and Ilko Naaborg (2007), Does foreign ownership foster bank performance?, Applied Financial Economics, 17, 881-885.

Lepetit, Laetitia and Frank Strobel (2013), Bank insolvency risk and time-varying Z-score measures, Journal of International Financial Markets, Institutions and Money, 25, 73-87. 
Lin, Huidan (2011), Foreign bank entry and firms' access to bank credit: Evidence from China, Journal of Banking \& Finance, 35, 1000-1010.

Luc Laeven (1999), Risk and efficiency in East Asian banks, World Bank Working Paper No. 2255

Martin Cihák and Heiko Hesse (2007), Cooperative banks and financial stability, IMF Working Paper No. 07/2.

Tacneng, Ruth (2015), The impact of minority foreign ownership and controlling shareholder on bank risk and performance: Evidence from an emerging economy, Managerial Finance, 41, 526-546.

Unite, Angelo A. and Michael J. Sullivan (2003), The effect of foreign entry and ownership structure on the Philippine domestic banking market, Journal of Banking \& Finance, 27, 2323-2345.

WB (2014), Financial sector assessment: Vietnam, World Bank East Asia and Pacific Regional Vice Presidency

------(2017), World Development Indicators, World Bank

Williams, Jonathan (2004), Determining management behaviour in European banking, Journal of Banking \& Finance, 28, 2427-2460.

$\mathrm{Xu}$, Ying (2011), Towards a more accurate measure of foreign bank entry and its impact on domestic banking performance: The case of China, Journal of Banking \& Finance, 35, 886901.

Yeyati, Eduardo Levy and Alejandro Micco (2007), Concentration and foreign penetration in Latin American banking sectors: Impact on competition and risk, Journal of Banking \& Finance, 31, 1633-1647. 